\begin{tabular}{|c|c|c|c|c|c|c|}
\hline \multirow{4}{*}{ Impact Factor: } & ISRA (India) & $=3.117$ & SIS (USA) & $=0.912$ & ICV (Poland) & $=6.630$ \\
\hline & ISI (Dubai, UAE & $=0.829$ & РИНЦ (Russia & $=0.156$ & PIF (India) & $=1.940$ \\
\hline & GIF (Australia) & $=0.564$ & ESJI (KZ) & $=8.716$ & IBI (India) & $=4.260$ \\
\hline & JIF & $=1.500$ & SJIF (Morocco & $=\mathbf{5 . 6 6 7}$ & OAJI (USA) & $=0.350$ \\
\hline
\end{tabular}

\begin{tabular}{|c|c|}
\hline $\begin{array}{l}\text { SOI: } \frac{1.1 / \mathrm{TA}}{} \\
\text { International Sc } \\
\text { Theoretical \& A }\end{array}$ & $\begin{array}{l}S \text { DOI: } 10.15863 / T A S \\
\text { ientific Journal } \\
\text { pplied Science }\end{array}$ \\
\hline p-ISSN: 2308-4944 (print) & e-ISSN: 2409-0085 (online) \\
\hline Year: 2019 & Volume: 72 \\
\hline Published: 30.04 .2019 & http://T-Science.org \\
\hline
\end{tabular}

SECTION 31. Economic research, finance, innovation, risk management.
QR - Issue

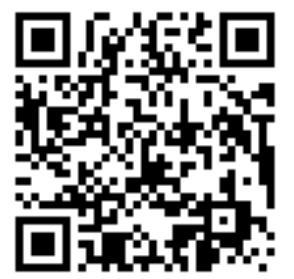

QR - Article

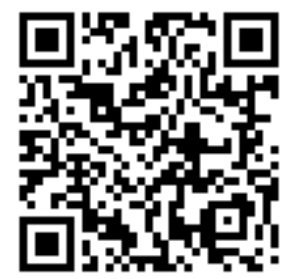

Narzillo Istamovich Rustamov

Ph.D, Tashkent state pedagogical university,

Tashkent, Republic of Uzbekistan

\title{
OPPORTUNITIES FOR STABLE TRANSFORMATIONS IN ECONOMICS AND THEIR EFFICIENT USAGE IN UZBEKISTAN
}

Abstract: This article discusses the structural changes in the sectors of the regional economy and their impact on economic growth and growth of the gross regional product. The author proposed measures to achieve effective structural reforms in the regional economies.

Key words: structural shifts, economic growth, structural shifts, economic growth, GDP, innovation.

Language: English

Citation: Rustamov, N. I. (2019). Opportunities for stable transformations in economics and their efficient usage in Uzbekistan. ISJ Theoretical \& Applied Science, 04 (72), 387-390.

Soi: http://s-o-i.org/1.1/TAS-04-72-50 Doi: crossef https://dx.doi.org/10.15863/TAS.2019.04.72.50

\section{Introduction}

In recent years, Uzbekistan has been paying more attention to improving the efficiency of structural changes in the economy. Particularly, the share of industry, services in the economy, while the share of agriculture in the economy is decreasing. As it is known, aggregate output of all sectors of the economy will be reflected in the indicator of gross domestic product (GDP) and implementation of structural changes in the economy will have a direct impact on the change in GDP. One of the methods of calculating GDP is the value added method that gives significant conclusions in the analysis of the composition of the GDP and the shifts in GDP, as determined by this method. The share of individual sectors in the total added value of the economy, its change, will allow to assess the state of development of the economy and the expected economic growth.

\section{Literature review}

Structural shifts in the economy have been thoroughly studied by leading economists of the world and have thoroughly analyzed the issue. In particular, the well-known economist P. According to Samuelson, "Structural changes in the consumption pattern determine the size and structure of the global demand, and the effects of long-term regulation of economic development on the structural adjustments in the field of savings. At the same time, structural changes in the consumption and savings sectors are the fundamental factors that contribute to the development of productive forces and production relations. Factors driven by macroeconomic dynamics include scientific and technical progress, changes in the preferences of consumer products, and the production factors. "[2, 452].

P. Kuznets notes that "economic growth in the country can be assessed with the ability to meet the growing needs of the population for a long time. These growth opportunities are based on the development of techniques and technologies, the essential changes in the structure of the economy and the ideology "[ 3 , 104].

Russian economist scientist N. Kondiratev believes that "there are certain limitations for the maintenance of the economic balance, which sometimes affects the balance of the economy. It turns out that the signs of the limitation and accuracy, the economic elements and the equilibrium of the situation, the appearance of such a phenomenon can lead to the emergence of economic equilibrium or the adequacy of the static state of the economy, and the emergence of special theories of statics. "[4, 298].

Y. Shumpeter believes that "the key momentum that drives the economic system will depend on the renewal of the consumer structure, the application of new methods of production and delivery of goods, the improvement of market activities, and the application of modern forms of economic management" [5, 122].

Structural shifts in national economy sectors are the result of technological, specialization, demand and a number of factors in the production process of the 


\begin{tabular}{|c|c|c|c|c|c|c|}
\hline \multirow{4}{*}{ Impact Factor: } & ISRA (India) & $=3.117$ & SIS (USA) & $=0.912$ & ICV (Poland) & $=6.630$ \\
\hline & ISI (Dubai, UAE & $=0.829$ & РИНЦ (Russia & $=0.156$ & PIF (India) & $=1.940$ \\
\hline & GIF (Australia) & $=0.564$ & ESJI (KZ) & $=8.716$ & IBI (India) & $=4.260$ \\
\hline & JIF & $=1.500$ & SJIF (Morocco & $=5.667$ & OAJI (USA) & $=0.350$ \\
\hline
\end{tabular}

economy. But the structural changes that are carried out by the influence of any factor are not always effective. The resulting structural changes in the economic sectors are the result of a period when the economic model of growth or decline in the economic life of the country.
Therefore, the socio-economic policy of the country is crucial to ensuring the effective transformation of the economy and ensuring sustainable economic growth. The article assesses the impact of factors on the overall factors that are a key factor in sustainable economic growth (Figure 1).

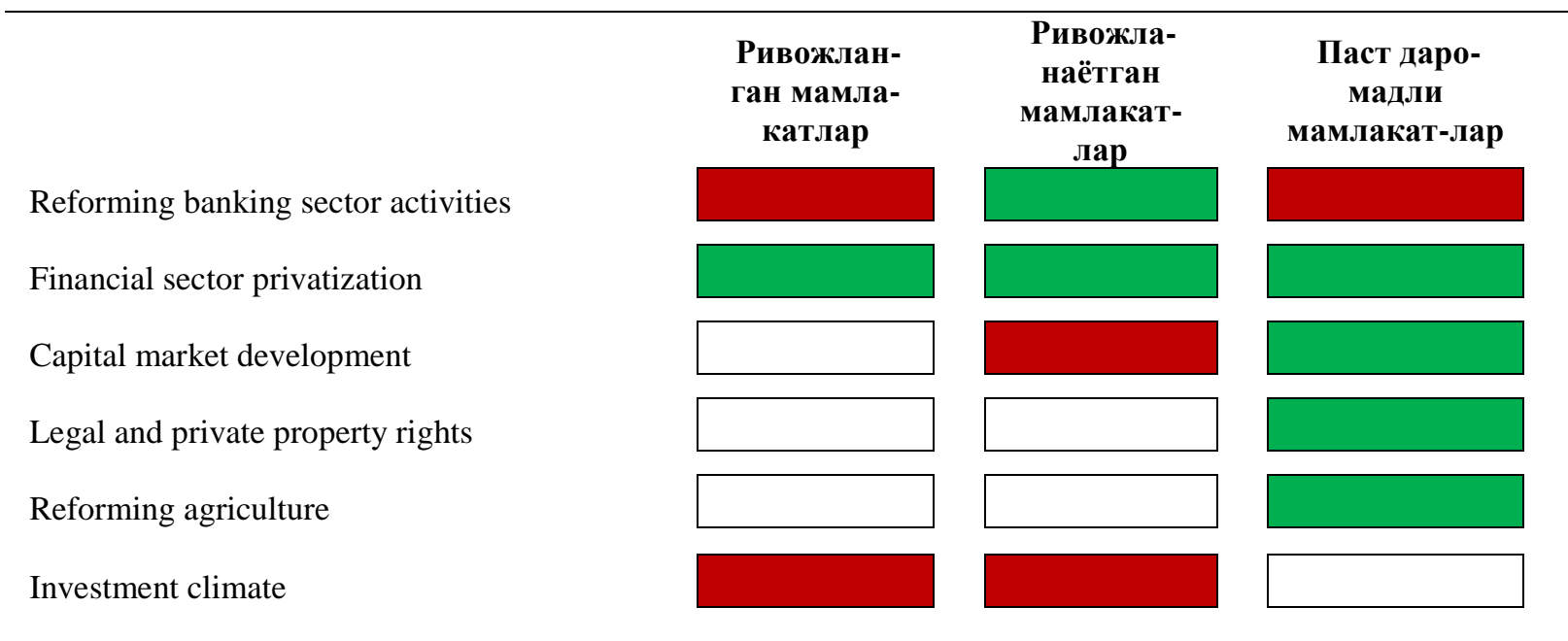

Influence on the effectiveness of aggregate factors in 5 years after the implementation of the reforms

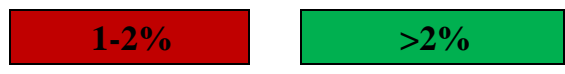

Fig.1. Increased effectiveness of structural reforms and aggregate factors.

As can be seen from Figure 1, banking sector reforms, privatization of the financial sector, the development of the capital market and the improvement of the investment environment for transition countries and low-income countries allow for effective structural transformation in sectors of the economy.

According to the International Monetary Fund, structural changes in the country's market economy are the basis for sustainable economic growth. Developing options for implementing structural changes in Uzbekistan, based on which, will help create scenarios for the development of the country's economy.

The development model of the country's economy up to 2008 has yielded fertility, including an average of 8.5 per cent of economic growth rates in 2000-2008, inflation at 4-5 per cent, devaluation of 10-15 per cent, average rate of USD exchange rate, positive balance of the budget (Fig. 2).

However, after 2008, the world economy recession (financial and economic crisis), the negative dynamics of prices of the main foreign commodity goods in the world market in 2014 and the sanctions of Russia and the West, one of the main trading partners of Uzbekistan, have had a negative impact on the economy of Uzbekistan. As a result, the problems that have aggravated for about 8 to 9 years have increased the likelihood of threatening the stability of the country's economy.

In order to overcome the burden of the economy and possible risks over the years, President of the Republic of Uzbekistan Sh. At the initiative of Mirzieyov, a number of reforms have been undertaken to radically change Uzbekistan's economic model and boost its competitiveness, including the Movement Strategy [1] in February 2017 to identify the target and sequence of all reforms, liberalization of pricing policy, liberalization of operations, step-by-step transition to market mechanisms of currency exchange rate formation, the distribution of raw materials on the basis of full market principles and many other measures were taken. It created the basis for radical changes in the national economy.

Based on the results of the study, the country is primarily affected by structural changes in the economy as a fundamental factor influencing the free movement of capital, the level of communication with the outside world, the free allocation of resources and the flexibility of labor resources, and the economic conditions that determine the factors of these factors. These factors were assessed as opportunities for structural change in the economic sectors (Figure 2). 


\begin{tabular}{|c|c|c|c|c|c|c|}
\hline \multirow{4}{*}{ Impact Factor: } & ISRA (India) & $=3.117$ & SIS (USA) & $=0.912$ & ICV (Poland) & $=6.630$ \\
\hline & ISI (Dubai, UAE & $=0.829$ & РИНЦ (Russia & $=0.156$ & PIF (India) & $=1.940$ \\
\hline & GIF (Australia) & $=0.564$ & ESJI (KZ) & $=8.716$ & IBI (India) & $=4.260$ \\
\hline & JIF & $=1.500$ & SJIF (Morocce & $=5.667$ & OAJI (USA) & $=0.350$ \\
\hline
\end{tabular}

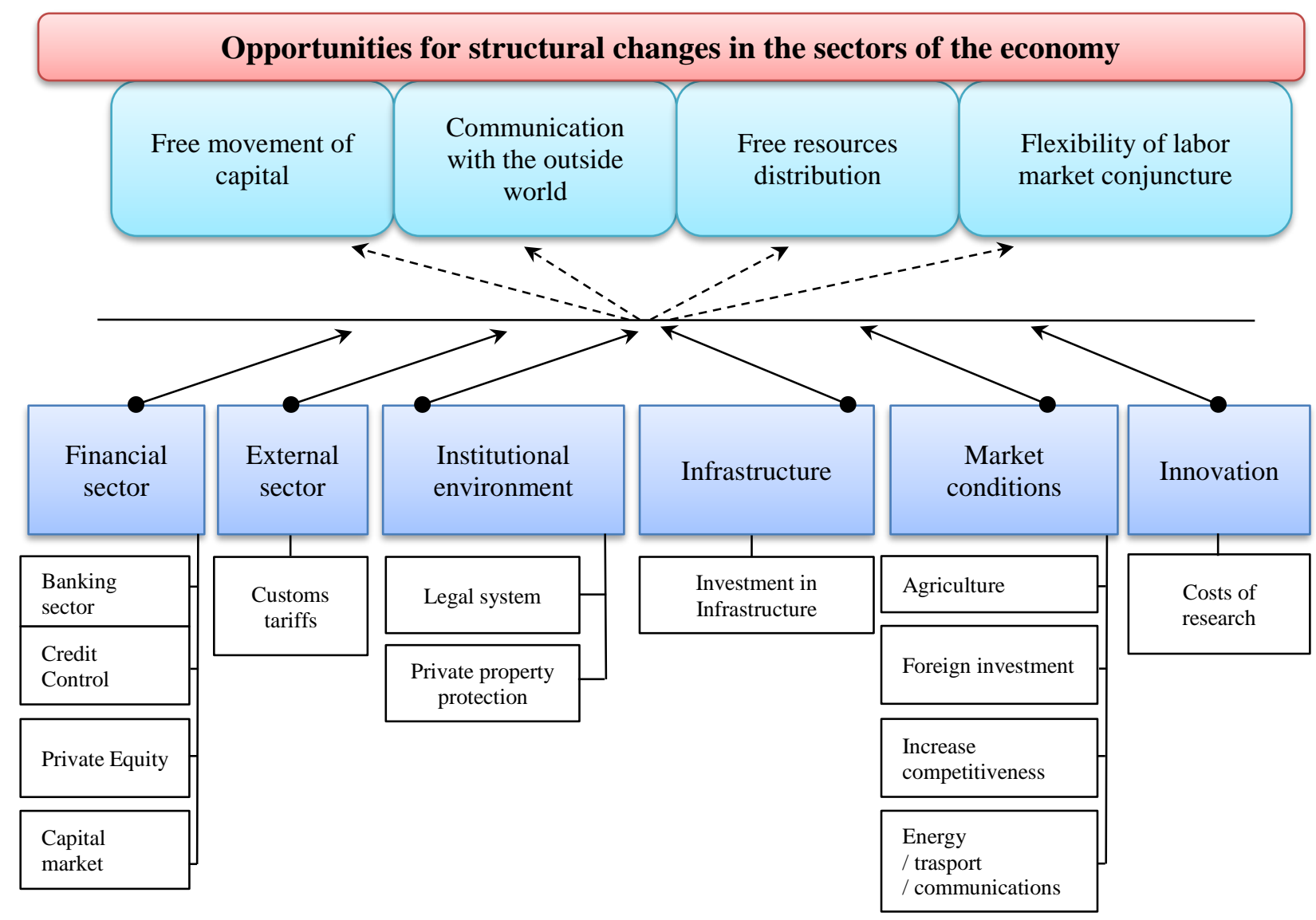

Fig.2. Possibilities of structural transformation in the sectors of the economy.

Figure 3 shows that in order to achieve structural transformations in the economy, it is necessary to prepare all infrastructure and regulatory legal frameworks for the freedom of capital movement, to introduce effective mechanisms of communication with the outside world, to form an institutional environment based on the formation of a competitive environment, the need to create a sufficient infrastructure for the market, a competitive environment in the markets, and a full freedom of action of innovation. i.

Let's look at the opportunities facing the structural transformation of the sectors of the economy one by one.

The financial sector constitutes the rule of the financial market managing the state for the movement of capital in the country, ie the banking system, the fiscal system, capital market, attracted investments, private equity, etc. By the end of 2018, there are 28 banks operating in the banking sector, of which 11 are state-owned banks. According to the results of 2018, the assets of the banking system increased by 128 percent compared to the respective period of the previous year, liabilities by 126.2 percent, loans by 148.9 percent and deposits by 119.7 percent. However, this growth was mainly attributable to the state banks, whose share in bank assets was 83.1 percent, liabilities - 83.3 percent, loans - 87.9 percent, deposits - 66.4 percent. As it is evident, the share of state-owned banks in the economy's investment was high, and 66.4 percent of state-owned banks operated bank deposit operations, one of the mechanisms providing money circulation in the economy [7]. This, in turn, means that most of the loaned loans are focused on public-private trusts. Moreover, the stock market in the Republic of Uzbekistan is weakly developed and the stock market capitalization is low. This indicates that the country's financial system is basically similar to a banking-based German model.

The external sector represents a set of economic policies, such as the country's customs policy and level of protectionism. In addition, it is understood that customs clearance procedures and costs incurred by the product are understood. Effective functioning of this sector ensures the stability of the domestic market and stability of the economy of the country. After the liberalization of the currency market in Uzbekistan in September 2017, the Decree of the President of the Republic of Uzbekistan "On measures to further regulate the foreign economic activity of the Republic of Uzbekistan" was adopted on September 29, 2017 in order to prevent the devaluation of the 


\begin{tabular}{|c|c|c|c|c|c|c|}
\hline \multirow{4}{*}{ Impact Factor: } & ISRA (India) & $=3.117$ & SIS (USA) & $=0.912$ & ICV (Poland) & $=6.630$ \\
\hline & ISI (Dubai, UAE & $=0.829$ & РИНЦ (Russia & $=0.156$ & PIF (India) & $=1.940$ \\
\hline & GIF (Australia) & $=0.564$ & ESJI (KZ) & $=8.716$ & IBI (India) & $=4.260$ \\
\hline & JIF & $=1.500$ & SJIF (Morocco & $=\mathbf{5 . 6 6 7}$ & OAJI (USA) & $=0.350$ \\
\hline
\end{tabular}

national currency on the country's domestic market. In line with this Resolution customs duties were revised and tariffs for certain goods nomenclature were zero, customs duties on certain commodity nomenclatures were reduced by 2 times. In addition, green corridors were built at airport customs. Individuals are allowed to bring consumer goods from neighboring countries to a certain level. As a result, the Republic of Uzbekistan has achieved 49.79 points in international trade (2017 44.31) in the Doing Business Business Index, annually published by the World Bank. [8]

Institutional environment. In the conditions of the socio-economic life of the country, a number of measures have been undertaken to improve the institutional environment of the country in recent years. In particular, the abolition of unscheduled inspections of entrepreneurs has been abolished, and the licensing and licensing procedures for business activities have been simplified and simplified.

Market conditions. In the recent years, a number of measures have been taken to introduce economic relations in the market economy, including a number of clusters in agriculture, the formation of prices for energy products, and the mechanism of main strategic distribution of goods through commodity exchanges.

Innovations. Innovative Development Strategy of the Republic of Uzbekistan has been adopted with the purpose of coordination and implementation of the main directions of innovation activity in the Republic and adoption of the Strategy of Innovative Development of the Republic of Uzbekistan, which will implement the Strategy of the Republic of Uzbekistan till 2030 The main directions for increasing the global index of indices were up to 50 levels.

\section{Conclusion}

Based on the above, it is possible to say that the opportunities created for the structural transformation in the economy of our country and the measures taken on their utilization ensure the development of our national economy and their improvement will contribute to the increase of Uzbekistan's international standing and reputation.

\section{References:}

1. (2017, February 8). The Decree of the President of the Republic of Uzbekistan dated February 7 , 2017 "On the Strategy for the Further Development of the Republic of Uzbekistan", N UP-4947. People's word.

2. Samuelson, P. A., \& Nordhaus, W. D. (2000). Economics. Per. s ang. Moscow: Labaratory bazovyx znaniy.

3. Kuznets, S. (2003). Sovremennyy ekonomicheskiy rost: rezul'taty issledovaniy $i$ razmyzhileniya: nobelevskaya lektsiya. Nobelevskie laureaty po ekonomike: vzglyad iz Rossii. SPb: Gumanistika.

4. Kondratev, N. D. (1991). Osnovnye problemy ekonomicheskoy statik $i$ dinamiki: Predvaritelnyy sketch. Moscow: Nauka.

5. Schumpeter, Y. (1989). Business Cycles. vol. 1.2. New York.

6. (n.d.). Information from the State Committee on Statistics of the Republic of Uzbekistan. Retrieved 2019, from www.stat.uz

7. (n.d.). Information of the Central Bank of the Republic of Uzbekistan. Retrieved 2019, from http://cbu.uz/uzc/statistic
8. Tursunov, B. O. (2017). osnovnye napravleniya podderzhki malogo biznesa $\mathrm{V}$ uzbekistane I zarubezhnyy opyt razvitiya predprinimatel"stva. Audit, № 6, pp. 34-38.

9. Ibragimov, I. U., \& Tursunov, B. O. (2017). enhancement the mechanism of analyzing of the methodological principles for the development and improvement of methods of assessment. Audit. 2017. № 4. S. 11-13.

10. Kasymov, S. S., Tursunov, B. O., \& Karimov, B. A. (2017). metody otsenki ekonomicheskoy nadezhnosti tekstil"nogo predpriyatiya $V$ usloviyakh rynochnoy ekonomiki. V sbornike: Teoriya i praktika organizatsii promyshlennogo proizvodstva. Effektivnost' organizatsii i upravleniya promyshlennymi predpriyatiyami: problemy i puti resheniya Materialy Mezhdunarodnoy nauchno-prakticheskoy konferentsii. Voronezhskiy gosudarstvennyy tekhnicheskiy universitet. (pp. 139-144).

11. (n.d.). World Bank Information. Retrieved 2019, from http://www.worldbank 
ISRA $($ India $) \quad=\mathbf{3 . 1 1 7}$ SIS $($ USA $) \quad=\mathbf{0 . 9 1 2}$ ICV $($ Poland $) \quad=\mathbf{6 . 6 3 0}$

Impact Factor:

ISI $($ Dubai, UAE $)=\mathbf{0 . 8 2 9}$ РИНЦ $($ Russia $)=\mathbf{0 . 1 5 6}$

GIF $($ Australia) $=0.564$ ESJI $(\mathrm{KZ}) \quad=8.716$

$\mathrm{PIF}$ (India) $\quad=1.940$

JIF

$=\mathbf{1 . 5 0 0}$ SJIF $($ Morocco $)=\mathbf{5 . 6 6 7}$

IBI (India)

$=4.260$

OAJI (USA)

$=0.350$ 
ISRA $($ India $) \quad=\mathbf{3 . 1 1 7}$ SIS $($ USA $) \quad=\mathbf{0 . 9 1 2}$ ICV $($ Poland $) \quad=\mathbf{6 . 6 3 0}$

Impact Factor:

ISI $($ Dubai, UAE $)=\mathbf{0 . 8 2 9}$ РИНЦ $($ Russia $)=\mathbf{0 . 1 5 6}$

GIF $($ Australia) $=0.564$ ESJI $(\mathrm{KZ}) \quad=8.716$

$\mathrm{PIF}$ (India) $\quad=1.940$

JIF

$=\mathbf{1 . 5 0 0}$ SJIF $($ Morocco $)=\mathbf{5 . 6 6 7}$

IBI (India)

$=4.260$

OAJI (USA)

$=0.350$ 